\title{
Conversion and the transformation of culture in the Finnish Pentecostal movement
}

A religious community is composed of and by its members. It both transforms and reflects their styles. This article argues that a crucial aspect of cultural change is the process of identitymaking through personal experience. In the development of any evangelical religious movement its second and third generations are especially important as they have a different experience of, and identification with, their religion than does the first generation. The Finnish Pentecostal movement has changed from being a radical to a more moderate movement because it has evolved in step with its members' socialization. Based on my fieldwork and research I want to emphasise this difference between the experiences of the first and subsequent generations in explaining how a religious movement changes.

\section{Introduction}

The Finnish Pentecostal movement (Helluntaiherätys) has a long history as a movement of the lower classes, and during that history it has been a relatively radical sect. As the second and subsequent generations of Pentecostals have experienced notable social upward mobility as a consequence of generational shifts and societal development however, the movement is now leaning towards middle-class positions and cultural styles, and can now be described as a relatively moderate denomination. Nevertheless, Pentecostalism in Finland in large part still attracts converts from the lower classes, and fosters radical Christianity within. This division between the converted lower-class and socialized middle-class members is manifested in many of the issues associated with the movement and its congregations, for example, in the division between radical and moder- ate, and in the various styles of religiosity and culture of which it is comprised.

In a situation like this one might expect those members who feel that there is a mismatch between their status and the style of the church to leave the church, or switch to other groups. This status-match hypothesis is supported by, for example, Rodney Stark and Charles Glock (1968), Jon P. Alston (1971), Robert H. Lauer (1975), and Frank Newport (1979). An alternative approach has been suggested by Darren E. Sherkat (1991) and Sherkat and John Wilson (1995), who state that not all who experience status-mismatch will change their religious group. A person is likely to stay in the group and change it from within if they have, for example, strong social ties to the group and its culture.

According to Rodney Stark and William Sims Bainbridge (1985), the generational shift is an important factor in determining how a movement changes from a sect into a denomination or church. They claim that the second generation will tend to be closer to the societal mean and will experience less tension with the outside world in comparison with the first. Of great importance for second-generation members is how the group culture will change over time. Moreover, on the basis on my research, I would agree that if the peers of a church member are experiencing the same social mobility and style change, it is more likely that they will stay in the group, even in the midst of cultural plurality and competing styles. Therefore the aspect of peer-support should not be overlooked.

In her research, Margaret M. Poloma (1989; Poloma and Green 2010) has analysed the change of the Pentecostal denomination called the Assemblies of God from, for example, the viewpoints of leader- 
ship and Thomas O'Dea's famous theory of the dilemmas of institutionalization (1961). In her works, Poloma has analysed the change from sect to denomination. Although she found that the groups of converted and socialized members differed in many aspects, she didn't examine this divide in full detail. Some of her findings do not seem to support the notion of a separation between radical and moderate Pentecostals between these groups. For example she found that 'converted and socialized adherents have a similar orientation towards evangelistic outreach' (Poloma 1989: 146-55). Since Poloma has not looked in detail at the radical/moderate question, no certain response can be given here in terms of a possible contradiction with the results of my research. One explanation could lie in the difference between Finnish and American cultures, and the social norm of 'normal' conduct. A Finn is less likely to be socially extrovert than an American, hence the different understanding of what is 'normal'. Moreover the meaning of what it is to be a radical or a moderate differs between cultures.

There has been a range of research projects undertaken on how sects transform into churches or denominations. Bryan R. Wilson (1990: 105-27) lists 'the principal determinants of sectarian evolution' as 'stance, structure, and orientation...; the implications of styles of leadership...; the character of organization; and the quality of denominational distinctiveness'. Roy Wallis (1975) has emphasized the role of leadership in differentiating the ideology as unique in the transformation of cult to sect.

In this article, I claim that a crucial factor in the transformation of a religious group is the generational shift and the respective differences across the generations in identity-making through religious experiences. Perceiving this dynamic will help us to understand how a religious group changes. Furthermore, it reveals how people find their social positions. My aim is first to show the connection between conversion experiences and decisions leading to different styles of religiosity and different social positions within the cultural framework and the context of group boundaries. Second, my aim is to demonstrate how this connection explains how it is that the Finnish Pentecostal movement, especially in the case of the larger congregations, has changed from being a lower-class sect to a middle-class denomination.

The mode and style of doing religion in Finnish Pentecostalism has been, as is common to Pente- costalisms around the world, a popular folk style, appealing to the common people and incorporating charismatic preaching, the expression of emotions and experience-based interpretations of one's faith (Martin 2002: 10-14; Mantsinen 2014). Radical religiosity, zealous preaching, and inexplicable experiences, such as speaking in tongues in public, do not always comply with the newly-acquired, middle-class style ideals that many current Finnish Pentecostals share. Instead they take their styles from a more moderate, middle-class repertoire.

In my research on the Finnish Pentecostal movement, which this article is also based on, one of the findings was the impact of a congregational culture on the social class positions of Pentecostal members. The impact is most visible with the socialized members, who have been immersed in the culture and were part of it when they chose the career paths which led to their current social positions. In some cases the adult first-generation converts have also experienced social mobility; usually when they found that their new religion and culture were not compatible with their current occupation or the culture they lived in. However these two groups and their decisions varied noticeably. (Mantsinen 2014)

The findings and analysis in this article are based on my research and fieldwork (2010-13) amongst Finnish Pentecostals, mainly in the Pentecostal Church of Turku. The research consists of systematic observation, interviews and surveys, as well as an archival and literature review. Based on this research I wrote my doctoral dissertation (Mantsinen 2014). The analysis in this article concentrates to a large extent on the qualitative aspects of my research and findings, mainly comprised of observation and interviews. Nevertheless, my surveys will confirm some details. In the future, a quantitative research and analysis would be welcomed, with a comparison between the different congregations and cultures.

\section{The context of the study and the concepts used}

The Finnish Pentecostal movement is a one hundredyear-old religious movement. With nearly 50,000 baptized and over 100,000 affiliated members it is the largest religious institution or network outside the Lutheran and Orthodox Churches (traditional churches with a special status in the Finnish legal system) in Finland. The Pentecostal Church of Turku has a congregation of over 1,500 baptized members. 


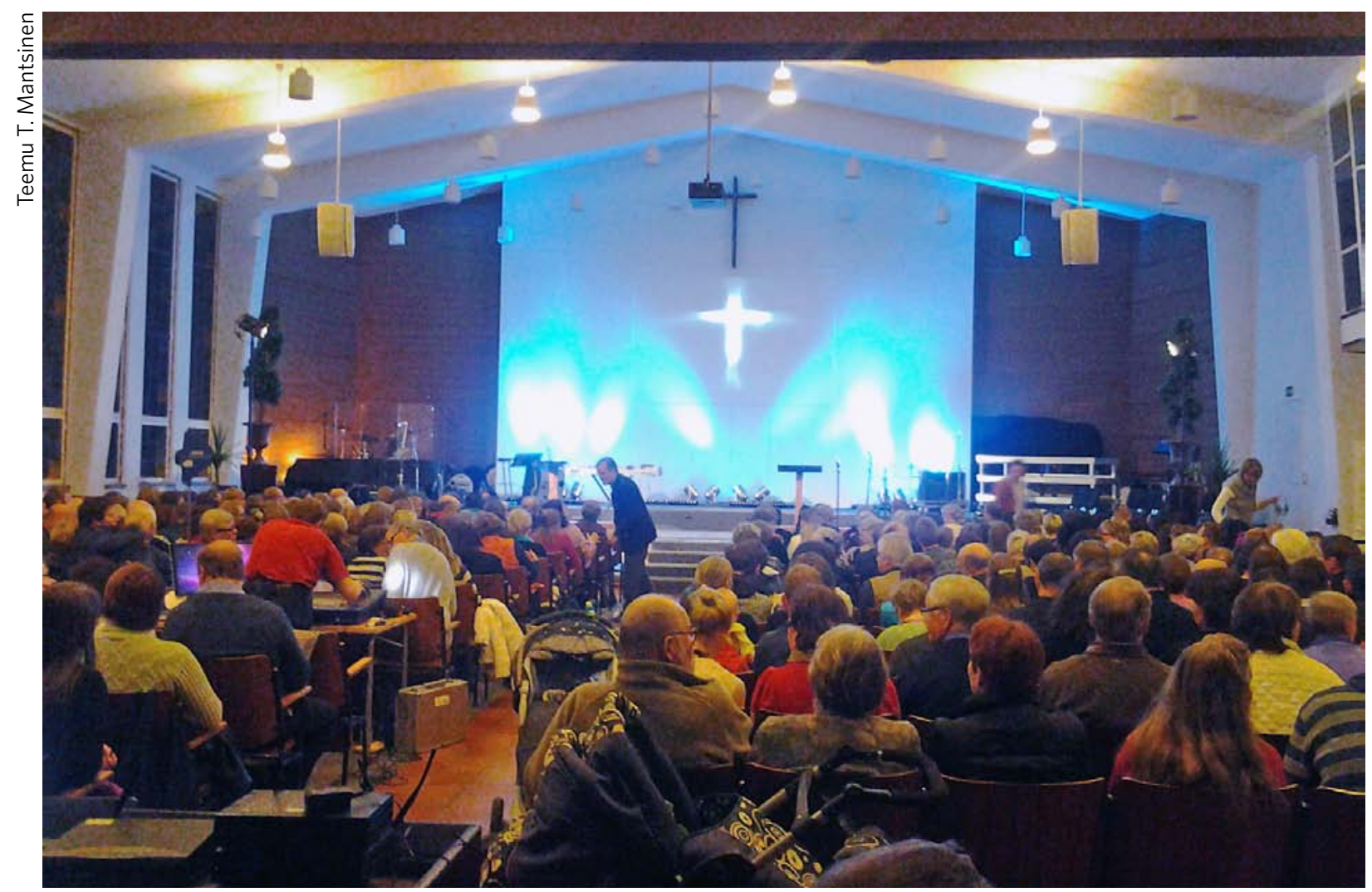

Turku Pentecostal Church, 15.11.2012.

Congregations in the movement emphasize independence, but are still closely connected to each other by a shared bible school, various organizations and mass events, including a summer conference. There are local variations among the congregations. They have various cultures and styles according to their size and leadership styles. The smaller congregations may maintain a closed culture, whereas the larger ones tend nowadays to be more pluralistic, moderate, and middle-class oriented. Also, an authoritative leader in a small congregation can mould his congregation into a more homogeneous whole (Mantsinen 2014). In this article, I concentrate on what that the larger congregations reveal about the movement.

One of the main findings from my research shows that the majority of Turku's Pentecostal Church members are in middle-class occupations. Furthermore both qualitative and quantitative analysis has confirmed that the congregational culture promotes certain occupations, styles and cultures, and therefore, a particular social-class mapping of the church. This became evident when I observed the social mobility of second and subsequent generations of Pentecostal members. Regression analysis of my survey of church members showed that one key factor that deter- mines upward social mobility was the number of Pentecostals in the family. The more Pentecostals there were in the family, the more evident was the upward mobility into certain favourable occupations and positions, of which many were such typically middle-class positions as doctors and teachers. Of the working-age members, 38 per cent of the converted members and 60 per cent of the socialized members were in middle-class positions. (Mantsinen 2014)

The theoretical finding was the fact that this process of finding one's social position can be explained as a process where a rationally selective individual makes decisions in the framework of his or her cultural boundaries. In order to be able to keep the integrity of his/her religion intact, an individual tends to make decisions that ensure their position in the congregation first and their social position only after that. Certain occupations are questionable mainly because of the culture they are understood to imply or promote. As an individual strives to find a career and a situation in which he/she 'feels right', the class culture of the various options is crucial. In the best scenario a person will describe his/her position as a vocation, and one that has been indicated to him/ her by God. (Mantsinen 2014) 
Furthermore, the culture offers ways of legitimizing certain actions within the Pentecostal member's specific cultural frame; in order to cross the cultural boundaries the member must deploy internal symbols and discursive rituals. A Pentecostal can best legitimize a questionable choice, occupation, career, or position by using the Bible as a sanctifying object in discursive rituals. Knowing the symbolic universe of one's culture can help an individual to navigate in the world and make culturally acceptable choices with more confidence. (Mantsinen 2014; Rappaport 1999: 50-2, 151-2, 427-37)

Pentecostalism is a mode of Christianity that is most famously associated with ecstatic experiences such as speaking in tongues and charismatic preaching and outreach, or evangelization. The way I approach Pentecostalism is to highlight those of its crucial aspects which can explain its dynamics and crosscultural expansion. Pentecostal religiosity is based on a three-fold cycle, which consists of an emphasis on discursivity, experience, and millenarianism. The millenarian beliefs in a new Pentecost, a Kingdom of God and the coming of Christ are experienced in various ways and interpreted through these personal experiences. Orally transmitted and interpreted stories of revivals and future hope are relatively easy to transmit cross-culturally through bodily experiences and an acceptance of local ontology, even as an oppositional field in this millenarian world view. In this article, I will not go into the detail of this dynamic, but I will rather concentrate on one experiential aspect of Pentecostalism; namely conversion, and its implications for social class. (Cox 1994, Robbins 2003, Vásquez 2009, Mantsinen 2014)

Conversion is a crucial aspect of the Pentecostal religion and its culture. It is the essential act of becoming a Pentecostal. One has to make a personal decision, to accept Jesus as a personal saviour', as the culturally-correct form has it. In Finnish Pentecostalism radical conversion experiences are still favoured, though not to the extent they used to be. In spite of this, many socialized Pentecostals share an experience of conversion which is very different; as an easy decision which might be described as simply choosing to follow the same path they have already started on - to continue on with one's culture

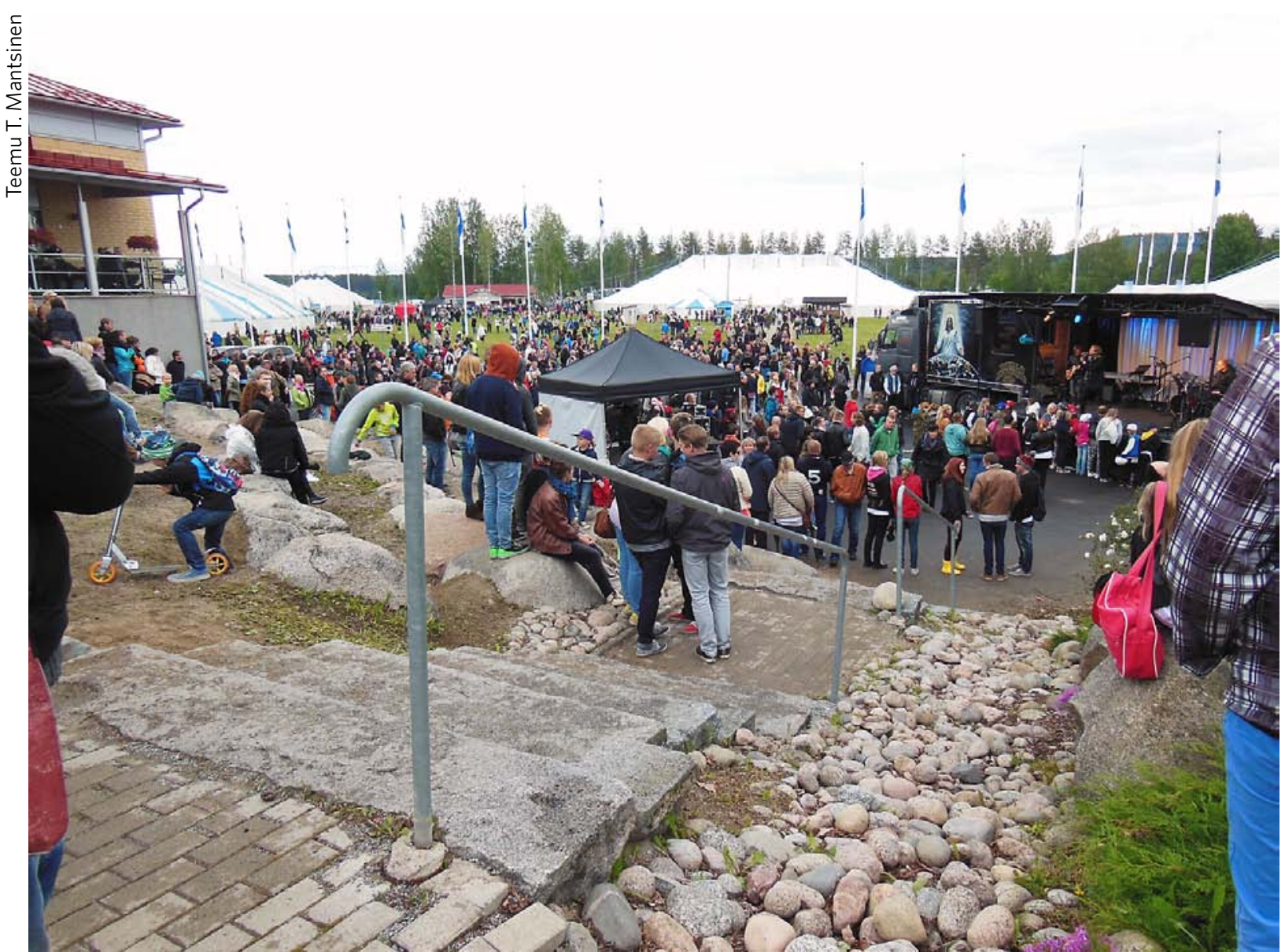

Pentecostal Summer Conference in Keuruu, Finland, 21.6.2014. 
of origin and upbringing. Nevertheless, the explicit act of conversion constructs Pentecostal identity; albeit very different forms of identity for converts who come in from the outside, on the one hand, and those from inside the movement on the other. Stories of strong experiences and emotions have a major function in making God more real. Therefore the conversion stories are not so much about accounts of actual events, but reconstructions of a social story and a shared experience. (Stromberg 1993: 118-19; Mantsinen 2009; Luhrmann 2012; Mantsinen 2014; Rambo and Farhadian 2014)

In this article, I refer to people who convert from the outside as 'converts' and distinguish those who convert on the inside, and have grown up in the movement, as 'socialized' members. Both groups share a discourse of conversion, but differ in their experiences and identities. People construct their identities through their personal experiences. Furthermore a distinction can be made between social, narrative and personal identities. The more a cultural group has power over an individual, the more social and narrative identities are emphasized (Markus and Nurius 1986, Partif 2011, Shoemaker 2011). This does not diminish the impact that individual experiences can have for the construction of personal identity. A socialized member in an open culture can construct his/her identity creatively, since he/she has intimate knowledge of its symbolic world and culture both intellectually and actively. This may in turn lead into experiences and feelings of a disjunction between one's individual status and group status.

People's identities are constructed out of their experiences and the process is affected by both internal and external schemas. An embodied self-image is mirrored by the social values, attitudes, and expectations the people around one have and are expected to have. Other important external factors include one's parents' religious (or non-religious) culture and traditions and the larger societal cultures characteristic of one's social position. If one's personal self-image and schema is at odds with the contextual social story and culture, the tension might be too great, forcing one to either change or make changes in one's social network - usually by switching from one group to another. (Mischel and Morf 2003, Cross and Gore 2003, Johnson 2007)

Up to a certain level class styles and styles of religiosity have a positive correlation - although not an independent relation. Social class is a contested concept, but it is nevertheless a useful term with which to describe the categorization of people in a hierarchical society. Furthermore, it is useful when one analyses inequalities and their causes. Society is the structure where social classes can emerge out of groups of people who have similar life circumstances. Social class positions are locations in the network of people in this society. Class cultures are formed based on similar interests, values, and practices, shared with people in similar positions, through, for example, shared educational experiences. (Bourdieu [1979] 2010, Crompton 2008, Bennett et al. 2009)

The difference between the class-cultural tastes and styles of, on the one hand the lower and on the other the middle-class positions is, for the purposes of this article, of major importance. The concomitant differences in positions relating to the social hierarchy, life experiences, and resources result in different ways of dealing with one's position, as well as in different attitudes towards life circumstances. It is typical of the middle-class desire to aspire to maintain the balance, and therefore the culture can be described as moderate. Since a certain status has been achieved, the middle classes can concentrate on cultivating their acquired skills. In the lower classes the lack of resources might lead to more radical attitude, since there is a motivation to improve one's social position and circumstances. People in deprived situations and positions, especially, tend to be looking for immediate results from the actions they take. (Weber [1946] 1991: 270-5, 313-21; Kraus et al. 2011)

Max Weber described the religion of the middleclasses as moderate; a style that would preserve the societal balance. The working classes, according to Weber, are driven by a need for change, and they tend to favour charismatic leaders and magic (Weber [1922] 1964: 80-117; [1946] 1991). The details of Weber's definition are called into question by, for example, historical and cultural differences. Nevertheless, these need-based styles and motivations do characterize the different class cultures. That being said, persons with different cultural backgrounds may disapprove of the class culture they currently find themselves in. For example, in my research one working-class, second-generation Pentecostal member shared his sense of a discrepancy between himself and his work colleagues, as they criticized and bad-mouthed their superiors - a thing that he as a Pentecostal would never think of doing. The more moderate and typically middle-class 


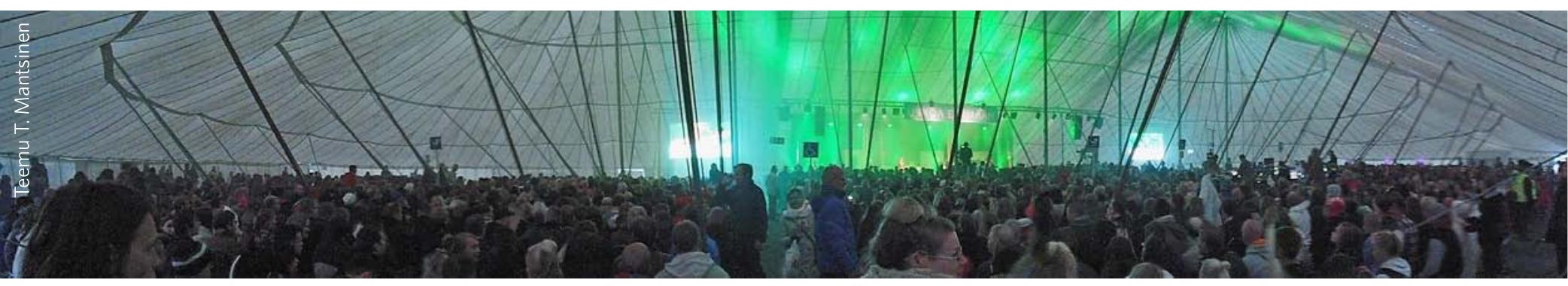

Youth meeting in Pentecostal Summer Conference in Keuruu, Finland, 21.6.2014.

attitude did not agree with the radical, working-class attitude. (Mantsinen 2014; Interview 1)

There are various styles, and more differences, nuances and connections between class positions and between conversion types, but for the purposes of this article I will concentrate on the impact of the difference between radical and moderate styles. This difference will, in my opinion, determine how the religious group will transform. The concepts 'radical' and 'moderate' require further definition. I will address these concepts as being relative to one another; as being located on a continuum or a scale. 'Radical religiosity' might be taken to imply violent behaviour, to which I am not referring here. Instead, when I use the term I simply refer to a style which differs notably from the surrounding culture and societal norms, and I use the term 'moderate style' to mean a style which affirms and maintains the cultural status quo of the environment. Therefore this selection follows somewhat that of the typology of church-sect division. (Cf. Weber [1922] 1964: 207-22)

\section{Results}

In my research on Finnish Pentecostalism, I have found that Pentecostal culture promotes certain social positions, of which many are middle-class. Favoured occupations include doctors, teachers, and various nursing and health care positions (Survey). The occupational cultures and vocational ideals are similar to those discourses I found in my interviews.

I have thought that it [teacher's profession] is a valid Christian occupation, that kids and youths, their well-being, is a thing which is in my heart. (Interview 2)
The construction of the congregational culture shared, overall, many of the values that middle-class culture entails; for example, sustaining the social balance, and valuing moderation and decent public conduct. The differences between socialized and converted members of the Pentecostal church was noticeable. The socialized members had been influenced by the congregational culture during their upbringing, and therefore were to be found occupying those positions that the culture promoted.

The congregational culture is shaped by multiple factors, including aspects of Finnish culture and religious history predating Pentecostalism and these factors combine in constructing a distinct group identity within certain historical settings, incorporating converts' and their descendants' positions and styles, a shared and constructed view of religion and its boundaries, and so on. The Finnish mentality and culture promotes a moderate and humble presence and presentation of self. This is reflected in the Finnish Pentecostal movement, especially if we compare it to Pentecostalism around the world. Personal and public conduct is relatively moderate and controlled in style. In the Finnish setting, Pentecostalism tends towards promoting a type of radicalism that focuses on the inner religious life and the emotional and mental spheres, and not necessarily on public demonstrations of religious faith.

When Pentecostal groups in Finland were new there was a need for a distinct identity, separate from mainline religion. This radical identity competed with the state church and challenged its legitimacy as the template for Christianity (Ruohomäki 2014). In subsequent decades the need to do this has decreased, due to personal experiences and the diminished role of the church in society. Many members are now found in middle-class positions, and the moderate aspect of culture has only become stronger in the 
movement. Furthermore, there has always been an aspect of control in Finnish Pentecostalism, whether it was in relation to dress or behavioural codes, or not allowing the emotions to overshadow teaching. (Mantsinen 2014)

In my research, I found out that the congregational culture of the Pentecostal Church of Turku promotes certain positions and lifestyles. The ideals of the helping professions (doctors, nurses) and education (teachers) are important, as is being 'civilized' and presenting a 'good example to outsiders' (i.e., controlling one's behaviour and following general social norms of appropriate behaviour; thus avoiding societal radicalism). An occupation that would be helpful, at least potentially, for spreading one's religion and its values, is easier to legitimate and explain as a vocation, a 'calling', and a good choice (Mantsinen 2014: 185-210). This type of culture recalls Weber's famous concept of the protestant ethic. It promotes hard and diligent work, but not in the exploitative, capitalist way that Marx criticized. (Cf. Weber [1905] 1965)

In the context of moderate Finnish culture and the Pentecostals' Christian moral teachings about decent conduct, the working-class, uneducated, unorganized and sometimes radical image was seen as an opposing culture, from which one should grow into a more Christian-like form conduct and lifestyle, through, supposedly, the help of God. This way of thinking demonstrates the ideal of becoming 'civilized'. This ideal is not so much a direct opposition of lower-class social positions, since they could be included in the repertoire in terms of the idea of suffering, which is also a favoured discourse in Pentecostalism, but it is an ideal of developing lowerclass members out of their positions and into better persons and Christians.

Simultaneously, as there has been an increase in the numbers of members in middle-class occupations, Finnish Pentecostal culture has reflected more and more these moderate styles and positions, rather than societal radicalism and societal change. Even though there has been an increasing interest in social work outside the church, the major objective for a Pentecostal member is still to be oriented towards the 'coming world'; to expedite the coming of Christ and to be prepared for the future.

When I conducted a statistical analysis of the working-age members of the Pentecostal Church of Turku and their answers to questions about social positions, a defining factor was their backgrounds.
The data revealed that there was an important difference between the socialized and converted social positions. The socialized members were predominantly situated in middle-class positions, whereas the positions of the converted members were usually lower and there was more variation within the group. The statistical analysis revealed that the difference did not trace back to their parents' situations. The origins were relatively parallel. The explanation was the existence of a Pentecostal background in the family. Furthermore my research confirmed the culture of the Pentecostal congregation as a defining factor. The occupations of socialized members reflected well the values and discourses of the congregation as a whole. (Mantsinen 2014; Survey)

Converted members did take into account the socially acceptable values, occupations and positions in their narratives during interviews, but their decisions had usually been made before conversion. Only if their occupation was in contradiction with the values of the group, did they feel the need for another career. For example, one woman described how she left her job as a waitress, tried and applied for couple of new forms of training and careers before she found her socially acceptable career in the security sector. As she said, 'hauling liquor to people' wasn't a job for a Christian (Interview 3). For those who had made a career decision more compatible with their values, the key question was how to legitimize their positions, if they didn't want to change their occupation.

Socialized members had possession of the cultural resources for legitimizing their decisions in the group more creatively, since they knew the language and culture thoroughly. Converted members relied in many cases on the most visible and well-established symbols and discourses. Therefore, a socially questionable choice was easier to make for a socialized than for a converted member. The availability of resources and means for adjusting their careers in accordance with their social identity imbues the socialized members a different image of self and better self-confidence with which they may construct their personal identities (see also Bermúdez 2011). An exception to this rule is the case where a welleducated convert joins the movement. In the beginning the language is adopted as mentioned above, but they will adapt to the situation relatively quickly. This exception nevertheless reinforces the trend towards a middle-class, moderate Pentecostalism in the long run. (Mantsinen 2009, 2014) 
These two groups were not only separated by the experience of upward social mobility. The difference in conversion experiences and processes was also of great importance. There was a noticeable separation between radical and moderate conversion, which furthermore shaped their religiosity. I had noticed this also in the research I did for my master's thesis. Back then I interviewed a group of young Pentecostal students to find out how they presented their religion and narrated their faith. The one interviewee who was converted from a totally non-Pentecostal background spoke of his belief in language which was characterized by an extremely strong Pentecostal vocabulary and phrases which used traditional symbols. Those who had more Pentecostals in their families narrated their religion more creatively, combining different symbols and using richer language. Part of the difference was due the educational background, but not in every case. (Mantsinen 2009)

For socialized members the Pentecostal religion represents cultural continuity. Therefore their religious identity is not so much about having made a choice - although that is a factor - than it is an expression of a world view and its stability. They continue along the path and engage in the symbolic world they have always known. Although they may present their religion in public discourse in traditional ways, they distance themselves from this language in private conversations. For example, the individual's moment of conversion is not a single event as it would be in the traditional discourse. Lacking this dramatic event, they construct their identities in terms of a negotiated awareness, not a transcendent revelation. During my research, I have met countless socialized Pentecostals, who share the sense of an absence of a single-moment or radical conversion. Many of them also have expressed their frustration and almost disgust for the social idealization of conversion stories which depict the development of the worst sinner into a perfect saint. They were brought up to be nice and decent children, and they simply lack experience of having led a shameful life, or an imperative to reject the world.

Socialized members do not necessarily understand radicalism in the workplace, as one of my interviewees explained. He had been brought up to respect authority, and he had never felt any need to rebel against anybody or anything. Furthermore, the group control would alienate those who weren't willing to fit in - or at least publicly to appear to fit in
- to this image of being 'a nice Christian'. Moreover, as the pastor of the Pentecostal Church of Turku said in interview, the unwillingness to go on strike, or uncertainty as to how to approach labour disputes is a characteristic of Finnish Pentecostals. (Interview 2, Interview 4)

From all this follows the fact that they tend to focus their efforts on preserving the status quo already achieved, improving the public profile and perceptions of their religion, placing an emphasis on 'normality'. There is usually no previous life or experiences from outside the Pentecostal cultural sphere. From this it follows that a socialized member has no personal, direct experience of otherness; they can only go on what they've heard in this respect. Therefore the personal identity continues to be one arising from a peaceful continuity, not disruption and separation, or aggressive radicalism. Accordingly, they comply with the moderate culture and reinforce it in their congregations.

For converted members, their religion is a choice, usually a radical choice if Pentecostalism is a minority culture. Therefore it follows that they are keen to differentiate themselves from past cultures and lifestyles, and emphasize the uniqueness of their world view. Their conversion is a process where the radical identity is not constructed only by the moment of decision, but also of the whole identity-making process, where this new identity is seen and constructed as radically different and sacred in contrast with a previous, profane lifestyle and cultural engagement. Also in contrast with the socialized member's experience, the conversion experience for outsiders is more characteristic of working-class culture. (See also BeitHallami and Argyle 1997: 114-38)

Since socialized members lack the experience of a dramatic conversion and all that it implies with regard to a Pentecostal self-identity, they tend to rationalize their religion at the cognitive level, quite distinctively. By this I mean that they deem moderate styles and consciously determined rationales to be more rational, or sensible, than radical, emotional and impulsive styles and rationales. For my socialized interviewees the former aspects are closer to their own experience of their identity and religion than the latter.

The way in which socialized members in the Finnish Pentecostal movement tend to construct their identities and present their religion produces styles and choices very much in accordance with typically middle-class values. This is especially evident when it 
comes to preserving one's social position. From this perspective, the former uneducated styles and forms of doing religion in the movement are seen as distasteful and are rejected. As a result the more orderly ways are seen as being sophisticated in the group, and the uncontrolled way inferior (see also Lawler 2005). In this way, socialized members of the Finnish Pentecostal movement construct a shared taste and culture, which opposes radical working-class culture and styles, and sees new converts, especially from the lower classes, as something to be civilized, making them more 'like us', good Pentecostal Christians. A socialized member prefers order over chaos in charismatic experiences and preaching styles, favours individual connections with god over group exaltation and individual diligence over purposeless performance. In many cases they lack the motivation and desire to pursue the highest positions of power, but aim for the positions of least resistance - in the middle.

Different conversion processes and personal histories divide these two groups in another respect also; namely when it comes to the process of becoming, and feeling, included in the group culture. For a socialized member the culture is already familiar. When the congregational culture is becoming more and more moderate, the moderate conversion preserves this objective. The situation in a radical conversion is very different. For lower-class converts it takes more time to adjust to the moderate culture than for middle-class converts. Even when the convert is from the middle class, his/her conversion experience does not help in this process. She or he might adjust to the culture better and faster, but there is still a sense of a mismatch in the beginning. As there are fewer converts now in the movement than previously, the socialized have the advantage not only of applying, but of changing the culture.

Thus, division between radical and moderate experiences has brought about a disjuncture in the culture of the movement. Moderation in the movement can be traced at least to two kinds of experiences. The first of these is that of a secularization of the surrounding society, which has brought the movement and the state church closer together, as they share the same enemy. Since the social tension has gone, or is substantially diminished, the support for radical religiosity has decreased. The second kind of experience is that of conversion without external tensions: the conversion experiences of socialized members, who do not share radical, dichotomous tensions between a 'previous life' and 'new life', and between 'institutionalized religion' and 'living faith' that the converts from the outside often have.

For the convert coming into the religion from the outside, the moment of decision and the adoption of a transformed personal identity is a focus for taking control of one's life circumstances. The new identity is consciously chosen and therefore it has to be defended (see also Davies 2011: 223-4). By sustaining a certain tension between their previous and current lifestyle and world view, a converted Pentecostal member relives the decisive moment and the adoption of the focal point of identity, making it emotionally closer and stronger.

The convert faces this dichotomous pattern many times in the process of constructing their personal and group identity, as well as in legitimizing their place in the religious group. Usually the convert tries to emphasize the traditional and sometimes stereotypical symbols and phrases, in order to establish their right to a place in the group. This process is crucial especially at the beginning of an individual's Pentecostal life, and is part of the learning curve involved in becoming proficient as a Pentecostal. Knowing the cultural world (its vocabulary and systems of thought and action) helps an individual to balance his/her religious identity with personal desires.

Since there is a lack of such a radical break from the outside world for the socialized member, the inner and innate attributes of personality are accentuated in identity formation. In public a socialized member may repeat the social story, but otherwise he/she reflects on his/her own experiences and adjusts his/ her personal identity story in that way. If personal experiences and the social story are irreconcilable, the resulting tension might lead to alienation from the group, unless there are enough compensating factors to balance the situation, such as peer-support.

For many socialized members in the movement the imperative quality of their religion - the imminent second coming of the Christ - has been difficult to accept. Childhood memories and stories of the end - social experiences and stories - were not in accord with their personal experiences of their faith and identity. For many socialized members this has resulted in a dismissal of eschatological ideas. As members of these generations have constructed their identities, a different kind of interpretation or expec- 


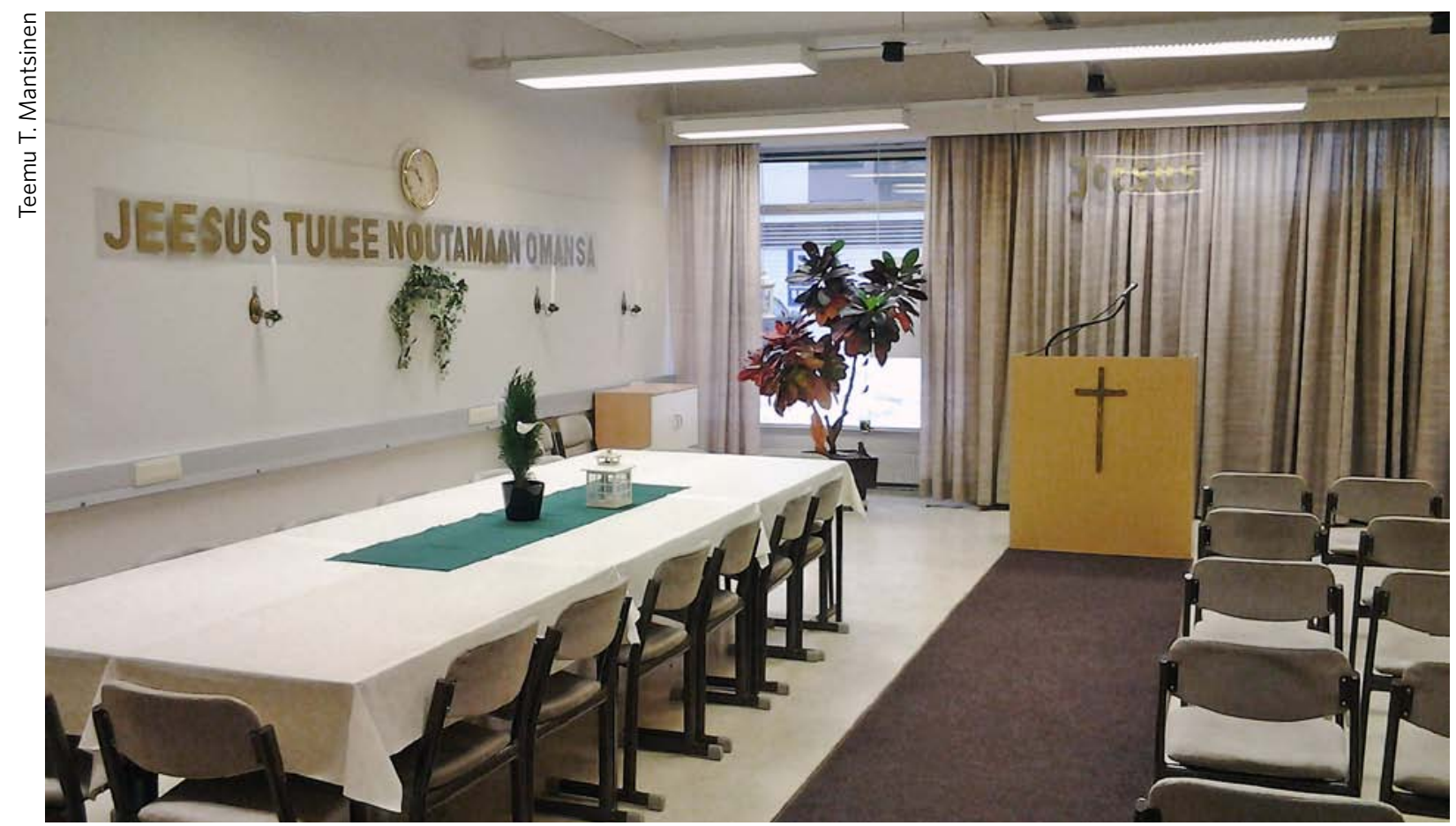

Wall text 'Jesus will come to gather his own' in a more traditional Pentecostal Church, 7.2.2013.

tation of the end has ensued: the end is not expected to be immediate, or at least that is not the greatest concern. Thus socialized members have imposed middle-class values, by sustaining both psychological and social balance, and rejecting radical, unexpected change. (Mantsinen forthcoming 2)

In my analysis of the transformation of the Finnish Pentecostal movement and the change occurring across the different generations, these intergenerational factors and varieties of experience have become a key explanation. Individual and generational experiences have transformed the movement to a large extent. Along with the conversion experience and the forms of religious identity it constructs, two distinctive styles of Finnish Pentecostalism have emerged as a result. This explains why change has been so hard to accept for some. In the movement two extreme groups have arisen, which can be labelled as organizational and charismatic, or moderate and radical groups. The fact of this division has been demonstrated by the founding of a state-registered Pentecostal Church and an oppositional association. These groups are distinguished as described here - by differences in conversion and generational experiences. (Mantsinen forthcoming)

The evolution of the movement has been possible largely because of three simultaneous historical devel- opments which occurred back in 1950s. Following the war, religious revivalism was strong and many converted to Pentecostalism. These converts had plenty of children - the big cohorts, or baby-boomers. These children benefitted from the societal developments that facilitated free education for all in the welfare society. The resulting moderate experiences and identity formations became the transforming force of the movement as these cohorts grew up and gained powerful positions in the movement. Once the growth of the movement stalled in 1980 s, new converts became the minority. Therefore the moderate experiences and styles have had the opportunity to become a formative factor and the defining feature of the movement.

One key factor in its evolution has been that the Finnish Pentecostal movement has been able to attract enough educated socialized members to maintain more or less active congregations. Since there has been a large basis - made up of the babyboomers - of upward mobility and moderate styles, there has been a sufficiency of peer support for socialized members. When people have a big crowd around them who share the same experiences and styles, they are more likely to stay within the group. Therefore the ideas put forward by Sherkat (1991) and Sherkat and Wilson (1995) apply also in the case of the Finnish Pentecostal movement. 
This development of the movement has not been without problems. The older and first generation Pentecostals might see the moderate styles as 'worldly', and the socialized members might see the radical styles as old-fashioned - leaving both sides unsatisfied (Mantsinen forthcoming). As the movement has evolved from being charismatic-led to being bureaucracy-led and more complex, the educated middle-class caucus have been able to promote the styles they prefer. This has led to the converted members feeling that there is a discrepancy between their experiences and personal identities and the developing social identity of the movement as a whole. It remains to be seen if the movement and congregations can achieve a balance between these two styles, and where this might lead.

The notion of moderation is nevertheless a relative concept. Since the ecstatic experiences of 'being baptized in the Spirit' and glossolalia - speaking in unknown tongues - have been pivotal for Pentecostal identity in the history of the movement, the lack of and even dismissal of these experiences could be seen as non-Pentecostal inside the movement. This has been demonstrated in different Pentecostal movements around the world (Poloma and Green 2010: 61-78). In the case of the Finnish Pentecostal movement, this kind of identity tension still exists at some level - at least in public discourse. Nevertheless, because the moderate, middle-class style Pentecostalism, influenced by Finnish culture, is the shared experience of a large crowd of socialized members, both the personal and social identities of being Pentecostal have changed to a large extent. Many inexplicable experiences are removed from the public to the private sphere. The need for a 'reasonable' and 'sensible' religion battles with the emotional and ecstatic experiences which are historically characteristic of the Pentecostal tradition.

\section{Conclusions}

In this article, I have described and analysed the different experiences and styles of religiosity of, on the one hand socialized and on the other, converted Pentecostal members, and how this difference has transformed the Finnish Pentecostal movement. The nature of their various conversion and identity-making experiences through this process have resulted in very different outcomes. The subtle experience of conversion, or group inclusion, of socialized mem- bers is closely linked to a move away from radicalism to moderation in the Pentecostal movement. In this light the radical conversion of outsiders, which in the past was a definitive feature of the movement, has become something to be controlled, or a matter of shame.

The conversion experience and the need to prove one's faith can be important in explaining how an individual finds their social position. The culture of an individual and their primary cultural group sets the boundaries according to which one may choose and legitimize one's affiliations, position and status. People do differ in the sense of the opportunities available to them to move in relation to these boundaries, based on their conversion experience and the extent of their cultural knowledge and involvement. There are other factors to be considered as well, such as previous history and what are the existing resources and modes of capital, but these cannot explain away the effect of conversion and group inclusion completely.

Conversion experiences are shaped by different histories and backgrounds, as well as social positions. Furthermore they also shape the identity of a believer and therefore shape the psychological boundaries within which an individual feels comfortable to move. This is also seen in the difference between the social positions and class cultures that individuals are willing to identify themselves with. Even though both could end up in same occupations and positions, the process seems easier for the socialized members, since they have internalized the culture and do not continuously have to prove that they belong to the group. The conversion experience, socialization into the group, and class styles all reinforce the styles and decisions of Pentecostal members. From this mixture of different styles and approaches to life, a congregation acquires its momentum to transform or reinvent itself.

Since the movement acquires its members nowadays more from the socialized group, who follow the movement's 'civilizing' teachings and values, and accordingly are finding middle-class occupations, it is the moderate religiosity that prevails. There are many factors benefitting this outcome of moderation over radicalism, but according to my research results, the conversion experience is a very important factor. The lack of a need to differentiate and distance oneself from a previous life and 'the world' can result in transforming a sect into a denomination. 
Therefore it is important to notice and study further the differences between the various experiences, and the constructions of identity that are effected in relation to them. In this article, I have demonstrated the importance of the difference between socialized and converted members and their experiences. A closer look at their situations can reveal how religious groups, in terms of their social structures and styles, have changed. Not only the older generations, but also many new converts from outside the movement share radical experiences and attitudes towards a 'previous' life and the 'world' outside the group. The educated members who are now in positions of power are socialized members, and they share much more moderate experiences and attitudes than the previous generations. Their moderation is partly a consequence of their education, but at the same time their education and career choices are influenced by their religious upbringing and moderate experiences.

This intertwining dynamic can explain in large part how the Finnish Pentecostal movement has changed from being a radical sect and moved closer to the Lutheran Church and society, to become a moderate and established religious denomination. As members of the new generations construct their identities out of moderate experiences and an idea of cultural continuity - not of disruption - at the same time they enforce middle-class values and styles, characterized by moderation and stability.

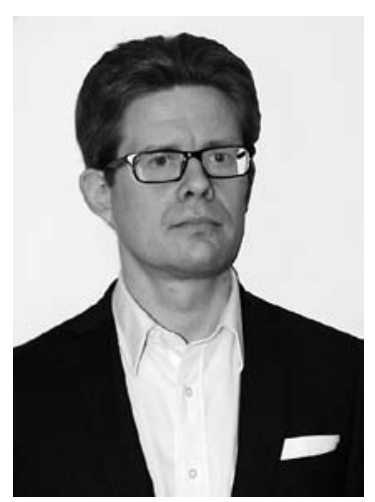

Teemu T. Mantsinen (PhD) is a post-doctoral researcher in Comparative Religion at the University of Turku, Finland. His doctoral dissertation (2014) focused on social class and Pentecostalism. His research interests include Pentecostalism, culture, rational choice and religion, cultural transformation and transmission and religious language and discourses.
Interview 4. Pastor of Turku Pentecostal Church, TKU/A/12/37

Survey. Working-age members of Turku Pentecostal Church 2010, TKU/O/13/1

\section{Bibliography}

Alston, Jon P., 1971. 'Religious mobility and socioeconomic status', Sociological Analysis, 32(3), pp. $140-8$

Beit-Hallami, Benjamin, and Michael Argyle, 1997. The Psychology of Religious Behaviour, Belief and Experience (London, Routledge)

Bennett, Tony, Mike Savage, Elizabeth Silva, Alan Warde, Modesto Gayo-Cal, and David Wright, 2009. Culture, Class, Distinction (London, Routledge)

Bermúdez, José Luis, 2011. 'Bodily awareness and selfconsciousness' in The Oxford Handbook of the Self, ed. Shaun Gallagher (Oxford University Press), pp. 157-203

Bourdieu, Pierre, (1979) 2010. Distinction (London, Routledge)

Cox, Harvey, 1994. Fire From Heaven: The Rise of Pentecostal Spirituality and the Reshaping of Religion in the Twenty-first Century (Boston, Addison-Wesley)

Crompton, Rosemary, 2008. Class and Stratification, $3 \mathrm{rd}$ edn (London, Polity Press)

Cross, Susan E., and Jonathan S. Gore, 2003. 'Cultural models of the self' in Handbook of Self and Identity, ed. Mark R. Leary and June Price Tangney (New York, The Guilford Press), pp. 536-64

Davies, Douglas J., 2011. Emotion, Identity, and Religion: Hope, Reciprocity, and Otherness (Oxford University Press)

Johnson, Mark, 2007. The Meaning of the Body: Aesthetics of Human Understanding (The University of Chicago Press)

Kraus, Michael W., Paul K. Piff, and Dacher Keltner, 2011. 'Social class as culture: the convergence of resources and rank in the social realm', Current Directions in Psychological Science, 20(4), 246-50

Lauer, Robert H., 1975. 'Occupational and religious mobility in a small city', Sociological Quarterly, 16(3), pp. 380-92

Lawler, Stephanie, 2005. 'Disgusted subjects: the making of middle-class identities', The Sociological Review, 53(3), pp. 429-46

Luhrmann, Tanya M., 2012. 'A hyperreal god and modern belief: toward an anthropological theory of mind', Current Anthropology, 53(4), pp. 371-95

Mantsinen, Teemu T., 2009. Normaali kristitty - helluntailainen. Uskosta kertomisen rakentuminen helluntailaisopiskelijoilla (University of Turku)

-2014. Helluntailaiset luokkakuvassa. Uskontokulttuuri ja yksilön luokka-asema Turun helluntaiseurakunnassa (University of Turku)

-Forthcoming. 'Between traditional and postmodern: internal struggles in the Finnish Pentecostal move- 
ment' in Anthology of Nordic Pentecostalism, ed. Jessica Moberg and Jane Skjoldli

-Forthcoming 2. 'The end is not our business: changed approaches on eschatology in Finnish Pentecostalism'

Markus, Hazel, and Paula Nurius, 1986. 'Possible selves', American Psychologist, 41(9), pp. 954-69

Martin, David, 2002. Pentecostalism: The World Their Parish (Malden, Blackwell)

Mischel, Walter, and Carolyn C. Morf, 2003. 'The self as a psycho-social dynamic processing system: a metaperspective on a century of the self in psychology' in Handbook of Self and Identity, ed. Mark R. Leary and June Price Tangney (New York, The Guilford Press), pp. $15-43$

Newport, Frank, 1979. 'The religious switcher in the United States', American Sociological Review, 44(4), pp. 528-52

O'Dea, Thomas, 1961. 'Five dilemmas in the institutionalization of religion', Journal for the Scientific Study of Religion, 1(1), pp. 30-41

Partif, Derek, 2011. 'The unimportance of identity' in The Oxford Handbook of the Self, ed. Shaun Gallagher (Oxford University Press), pp. 419-41

Poloma, Margaret M., 1989. The Assemblies of God at the Crossroads: Charisma and Institutional Dilemmas (Knoxville, The University of Tennessee Press)

Poloma, Margaret M., and John C. Green, 2010. The Assemblies of God: Godly Love and the Revitalization of American Pentecostalism (New York University Press)

Rambo, Lewis R., and Charles Farhadian (eds), 2014. The Oxford Handbook of Religious Conversion (New York, Oxford University Press)

Rappaport, Roy A., 1999. Ritual and Religion in the Making of Humanity (Cambridge University Press)

Robbins, Joel, 2003. 'On the paradoxes of global Pentecostalism and the perils of continuity thinking', Religion 33(3), pp. 221-31

Ruohomäki, Jouko, 2014. Suomen helluntailiikkeen synty, leviäminen ja yhteisönmuodostus 1907-1922 (Keuruu, Aikamedia)

Sherkat, Darren E., 1991. 'Leaving the faith: testing theories of religious switching using survival models', Social Science Research, 2o(2), pp. 171-87

Sherkat, Darren E., and John Wilson, 1995. 'Preferences, constraints, and choices in religious markets: an examination of religious switching and apostasy', Social Forces, 73(3), pp. 993-1026

Shoemaker, Sydney, 2011. 'On what we are' in The Oxford Handbook of the Self, ed. Shaun Gallagher (Oxford University Press), pp. 352-71

Stark, Rodney, and Charles Glock, 1968. American Piety: The Nature of Religious Commitment (Berkeley, University of California Press)

Stark, Rodney, and William Sims Bainbridge, 1985. The Future of Religion: Secularization, Revival, and Cult Formation (Berkeley, University of California Press)

Stromberg, Peter G., 1993. Language and Self-transformation: A Study of the Christian Conversion Narrative (Cambridge University Press)
Vásquez, Manuel A., 2009. 'The global portability of pneumatic Christianity: comparing African and Latin American Pentecostalisms', African Studies, 68(2), pp. 273-86

Wallis, Roy, 1975. 'The cult and its transformations' in Sectarianism: Analyses of Religious and Non-Religious Sects, ed. Roy Wallis (London, Peter Owen), pp. 35-49

Weber, Max, (1922) 1964. The Sociology of Religion (Boston, Beacon Press)

-(1905) 1965. The Protestant Ethic and the Spirit of Capitalism (London, Allen \& Unwin)

-(1946) 1991. Essays in Sociology (London, Routledge)

Wilson, Bryan R., 1990. The Social Dimensions of Sectarianism: Sects and New Religious Movements in Contemporary Society (Oxford, Clarendon Press) 